\title{
Synthesis of new aza- $C$-disaccharides using cycloaddition reaction of five member chiral cyclic nitrones to alkenes derived from glucose and galactose
}

\author{
Nikolaos G. Argyropoulos, * Evdoxia Coutouli-Argyropoulou, and Petros Gkizis \\ Department of Chemistry, Laboratory of Organic Chemistry, Aristotle University of \\ Thessaloniki, 54124 Thessaloniki, Greece \\ E-mail:narg@,chem.auth.gr
}

\begin{abstract}
Aza-C-disaccharides were obtained in high yields using as the key reaction for the $\mathrm{C}$-C bond formation the 1,3-dipolar cycloaddition of sugar derived cyclic nitrones with sugar derived alkenes. The observed diastereoselectivity of the reactions is rationalized on the basis of substituent induced steric factors and hydrogen bond formation.
\end{abstract}

Keywords: Disaccharides, nitrones, 1, 3-dipolar cycloaddition, D-glucose, D-galactose

\section{Introduction}

Azasugars have attracted much interest in recent years due to their ability to act as glycosidase inhibitors and hence to have potential applications in the treatment of metabolic diseases (diabetes), cancer and viral diseases. ${ }^{1}$ Since many glycosidase display selectivity towards the aglycon part of the inhibitor, the attachment of a second aglycon-mimicking sugar unit to an azasugar is expected to enhance its selectivity and effectiveness as inhibitor. In this context azasugars linked to common monosaccharides by a nonhydrolyzable $\mathrm{C}$ - $\mathrm{C}$ bond, namely the aza$C$-disaccharides are promising substrates as selective glycosidase inhibitors and have become attractive synthetic targets. ${ }^{2,3}$

Since the synthesis of the first aza- $C$-disaccharide by Johnson and co-workers several synthetic approaches towards this class of compounds have been reported including, as the key step for the C-C forming reaction, Suzuki couplings, Barbier reactions, Wittig olefinations, double reductive aminations, cross-aldolization reaction, Nosaki-Kishi couplings, aldol condensation reactions. ${ }^{3}$

Recently, we have described the synthesis of the branched chain aza-C-disaccharide $\mathbf{3}$ applying as the key step the stereoselective cycloaddition of the chiral open chain nitrone $\mathbf{1}$ to the sugar derived alkene 2. ${ }^{4}$ Although nitrone cycloadditions have been found extended applications 
in sugar chemistry, ${ }^{5}$ to the best of our knowledge there are only two more references dealing with their usage for the synthesis of aza- $C$-disaccharides. ${ }^{6}$ In an effort to expand the scope of this approach we initially examined the reactions of the nitrone $\mathbf{1}$ with the monosubstituted alkenes $\mathbf{4}$ and $\mathbf{5}$ derived from D-glucose and D-galactose respectively. ${ }^{7}$ However, these alkenes gave inseparable mixtures of diastereoisomers in low yields, probably as a result of their low reactivity due to the absence of the activating ester group. Therefore we focused our approach to the five membered chiral nitrones 6 and 7, which are expected to be more reactive. Furthermore these nitrones offer a ready pyrrolidine ring for the construction of the aza- $C$-disaccharide skeleton.

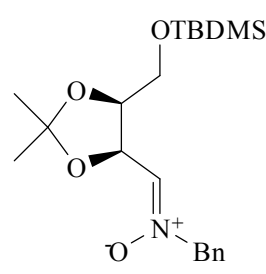

1
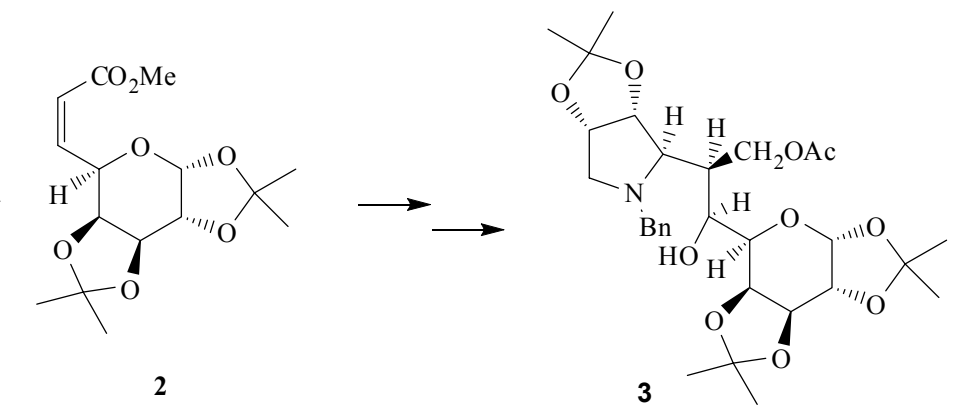

\section{Results and Discussion}

Nitrone 7 was prepared from D-ribose and its synthesis and applications to the preparation of pyrrolidine and pyrrolizidine derivatives have been previously described by us. ${ }^{8}$ Nitrone 6 was prepared from D-arabinose and its synthesis and application as intermediate for the total synthesis of pyrrolizidine alkaloids hyacinthacine $\mathrm{A}_{2}$ and 7-deoxycasuarine have been previously described by different research groups. ${ }^{9}$ Nitrones 6 and 7 have been also used by us for the synthesis of bicyclic isoxazolidine nucleoside analogues. ${ }^{10}$
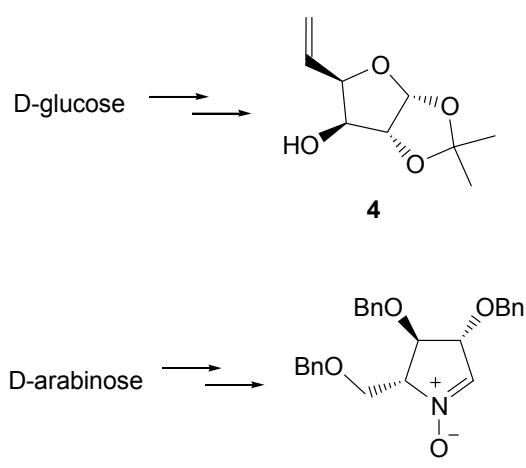

6

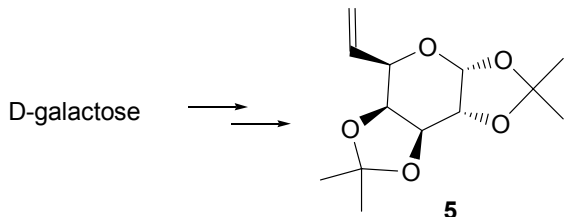

D-ribose

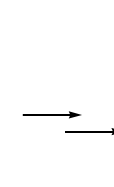




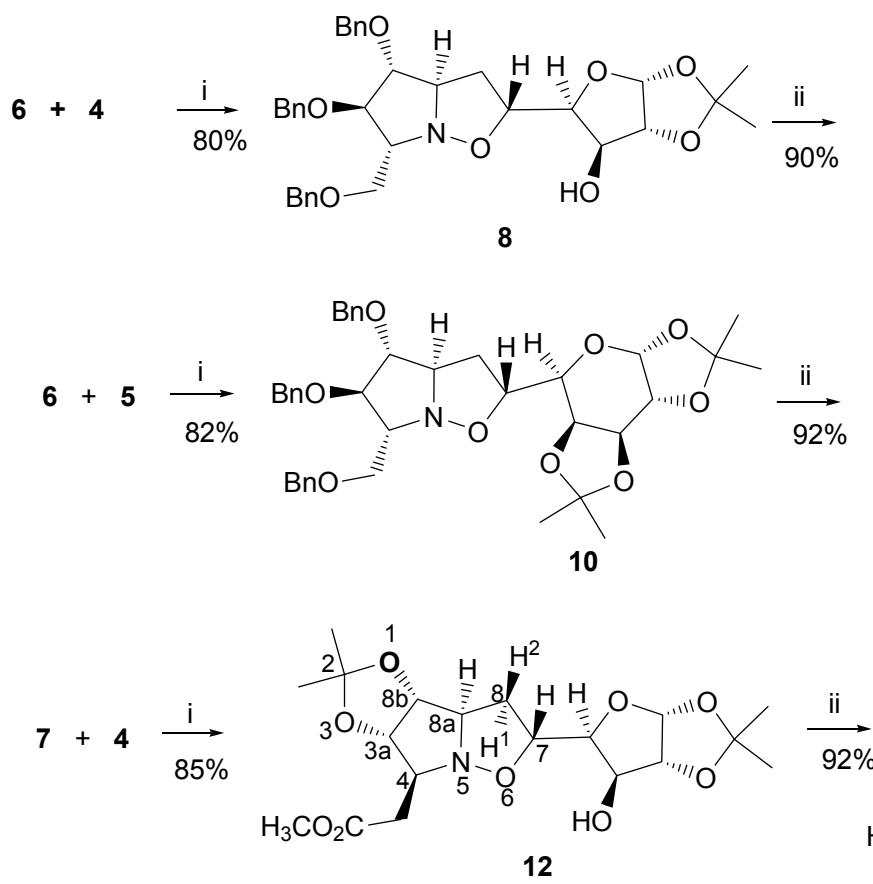

12

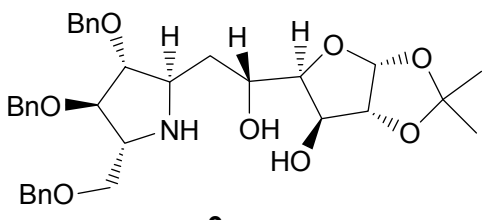

9

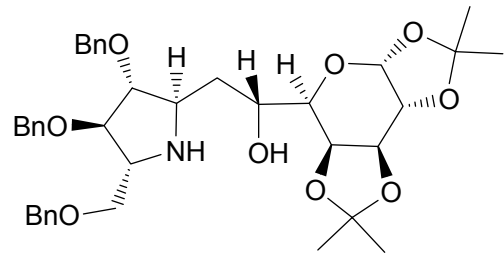

11

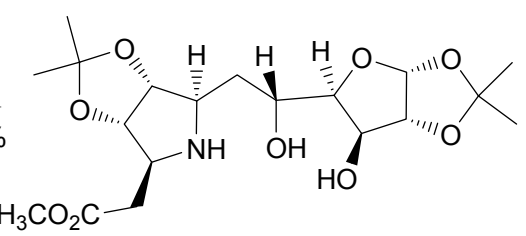

13

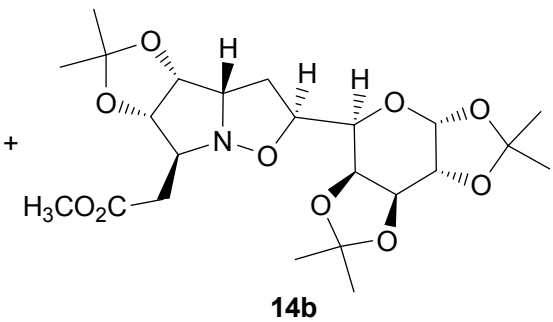

$95 \% \downarrow$ ii

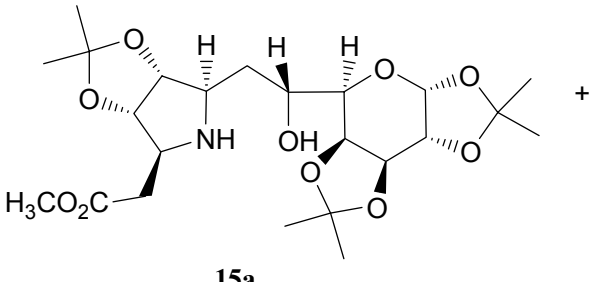

15

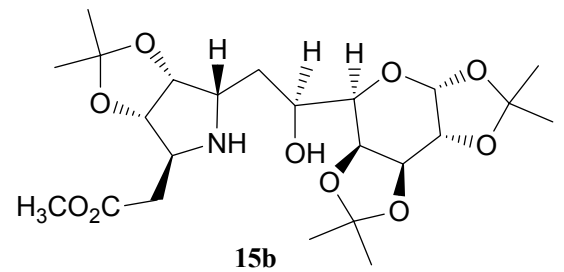

Scheme 1. Reagents and conditions: i) $\mathrm{CH}_{2} \mathrm{Cl}_{2}$, reflux, 3-4 days. ii) $\mathrm{CH}_{3} \mathrm{OH}$, Raney $\mathrm{Ni}, \mathrm{H}_{2}$, r.t, 2 days.

The reactions between nitrones $\mathbf{6}$ and 7 with alkenes 4 and 5 were carried out by refluxing equimolecular amounts of the reactants in dry dichloromethane under an argon atmosphere until the disappearance of the starting compounds (about 3 or 4 days). The reactions of both nitrones 6 and 7 with the alkene 4 were highly diastereoselective and only one diastereoisomer 8 and 12 respectively was obtained from each reaction in $80-85 \%$ yield (Scheme 1). The reaction of 
nitrone $\mathbf{6}$ with alkene 5 was also diastereoselective and only isomer $\mathbf{1 0}$ was isolated in $82 \%$ yield from the reaction after column chromatography, although traces of a second isomer were detected in the crude reaction mixture. However, the reaction of nitrone 7 with alkene 5 resulted in an inseparable mixture of two diastereomers $\mathbf{1 4 a}$ and $\mathbf{1 4 b}$ in a ratio $3: 2$ as it was determined from its ${ }^{1} \mathrm{H}$ NMR spectrum.

Reductive cleavage of the $\mathrm{N}-\mathrm{O}$ bond of the obtained isoxazolidine cycloadducts $\mathbf{8}, \mathbf{1 0}$ and 12 carried out by catalytic hydrogenation over Raney $\mathrm{Ni}$ gave almost quantitatively the corresponding aza- $C$-disaccharide derivatives 9, 11 and 13 respectively (Scheme 1). This reductive cleavage was also attempted to the mixture of compounds $\mathbf{1 4}$ with the expectation to separate the reduction products. However an inseparable mixture of aza- $C$-disaccharides 15a and $15 \mathrm{~b}$ was obtained.

The structure elucidation of the obtained cycloadducts was mainly based on their spectral data. In particular the discrimination between the possible stereoisomers was based on ${ }^{1} \mathrm{H}$ NMR data. ${ }^{1} \mathrm{H}$ NMR assignments, where it was possible, were confirmed by double resonance experiments. The proposed regiochemistry is in accordance to the well established regiochemistry of cycloadditions of nitrones with monosubstituted alkenes as dipolarophiles where the formation of 5-substituted isoxazolidines predominates, ${ }^{11}$ and it is strongly supported by the chemical shift of isoxazolidine methylene protons which appear as ddd or multiplets at $\delta$ 2.27-2.56, characteristic values of 4-isoxazolidine protons. For 5-substituted isoxazolidines there are four possible diastereomers arising from the exo/endo approach of dipolarophile and also from the $R e$ and the $S i$ face of the reacting nitrone (Scheme 2). Between these four possible diastereomeric structures the obtained products 8, 10 and 12 were assigned as Re-exo cycloadducts.
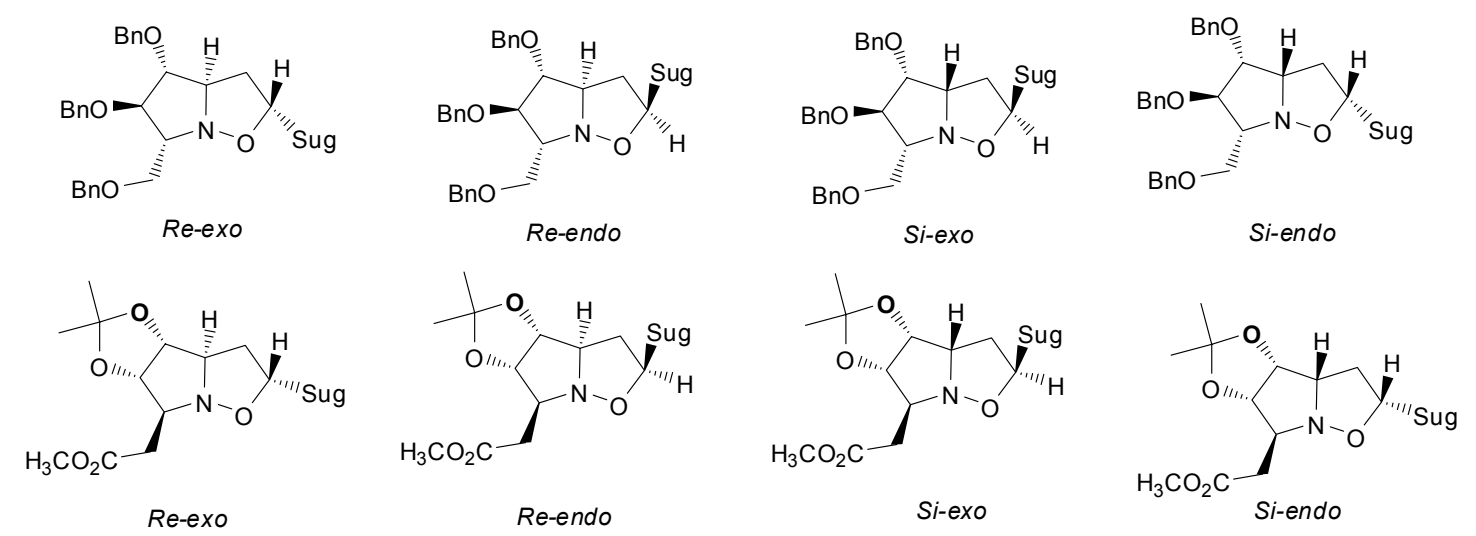

Scheme 2. Possible 5-substituted isoxazolidine diastereoisomers from the reactions of nitrones 6 and 7 and sugar derived alkenes.

In compound 8 the two methylene isoxazolidine protons $\left(3^{\prime}-\mathrm{H}\right)$ appear at $\delta 2.32$ (ddd, $J_{\text {gem }}=$ $\left.12.8 \mathrm{~Hz}, J_{3^{\prime} \mathrm{H}^{1}, 3 \mathrm{a}^{\prime} \mathrm{H}}=8.2 \mathrm{~Hz}, J_{3^{\prime} \mathrm{H}^{1}, 2^{\prime} \mathrm{H}}=5.9 \mathrm{~Hz}\right)$ and $2.45\left(\mathrm{ddd}, J_{\text {gem }}=12.8 \mathrm{~Hz}, J_{3^{\prime} \mathrm{H}^{2}, 3 \mathrm{a}^{\prime} \mathrm{H}}=4.1 \mathrm{~Hz}\right.$, $J_{3^{\prime} \mathrm{H}^{2}, 2^{\prime} \mathrm{H}}=7.7 \mathrm{~Hz}$ ) each one having one large and one smaller coupling constant with its 
neighbouring protons indicative that it is trans to one of them and cis to the other, as it holds for an exo adduct in which the $3 \mathrm{a}^{\prime}-\mathrm{H}$ and $2^{\prime}-\mathrm{H}$ of the isoxazolidine ring have a trans disposition. The approach from the $R e$-face of the nitrone which leads the $3 \mathrm{a}^{\prime}-\mathrm{H}$ to be on the same side with $5^{\prime}-\mathrm{H}$ was evidenced by NOE measurements as depicted in Figure 1. The significant mutual enhancements between $3 \mathrm{a}^{\prime}$ with $5^{\prime}-\mathrm{H}$ as well those between $3^{\prime}-\mathrm{H}^{2}$ and $4^{\prime}-\mathrm{H}$ strongly support the proposed structure. The ${ }^{1} \mathrm{H}$ NMR spectrum of compound $\mathbf{1 0}$ in $\mathrm{CDCl}_{3}$ was not very helpful, since most of the peaks crucial for structure determination were overlapped. Fortunately, in the ${ }^{1} \mathrm{H}$ NMR in $\mathrm{CDCl}_{3} / \mathrm{C}_{6} \mathrm{D}_{6}$ solution (see experimental part) some of the peaks were resolved and permitted NOE measurements, which support the proposed structure (Figure 1). Thus, the mutual NOE enhancements between $3-\mathrm{H}^{2}$ with both $4-\mathrm{H}$ and $2-\mathrm{H}$ show that these protons are on the same internal side of the ring system, as it comes out from a Re-exo approach. This is further evidenced from the mutual NOE increments between 2-H and 6- $\mathrm{H}$. In the ${ }^{1} \mathrm{H}$ NMR spectrum of compound 12 many of the crucial peaks were also overlapped. Several solvent mixtures were tested and the best resolution was obtained in $\mathrm{CDCl}_{3} / \mathrm{C}_{6} \mathrm{D}_{6}$ 3:1 mixture. Even in this mixture there were many overlappings, but the two $8-\mathrm{H}$ and $8 \mathrm{a}-\mathrm{H}$ were resolved and their measured coupling constants give evidence for the proposed structure. Thus, $8 \mathrm{a}-\mathrm{H}$ appears at $\delta 3.82$ as dd with $J_{8 \mathrm{aH}, 8 \mathrm{H}^{1}}=8.0 \mathrm{~Hz}$ and $J_{8 \mathrm{aH}, 8 \mathrm{bH}}=2.4 \mathrm{~Hz}$, whereas $J_{8 \mathrm{aH}, 8 \mathrm{H}^{2}}$ is zero (see Scheme 1 for numbering). The small coupling constant between $8 \mathrm{a}-\mathrm{H}$ and $8 \mathrm{~b}-\mathrm{H}$ is indicative that these protons are in trans disposition, as it holds for cycloadducts from the $R e$-face. The two 8-H appear at $\delta$ $2.39\left(\mathrm{ddd}, J_{\mathrm{gem}}=13.0 \mathrm{~Hz}, J_{8 \mathrm{H}^{1}, 8 \mathrm{aH}}=8.0 \mathrm{~Hz}, J_{8 \mathrm{H}^{1}, 7 \mathrm{H}}=5.8 \mathrm{~Hz}\right)$ and $2.56\left(\mathrm{dd}, J_{\mathrm{gem}}=13.0 \mathrm{~Hz}\right.$, $J_{8 \mathrm{H}^{2}, 7 \mathrm{H}}=8.9 \mathrm{~Hz}$ ). The $8-\mathrm{H}^{2}$ at $\delta 2.56$ with a zero coupling constant with $8 \mathrm{a}-\mathrm{H}$ and so trans to it exhibits the larger coupling constant with $7-\mathrm{H}\left(8.9\right.$ versus 5.8 of $\left.8-\mathrm{H}^{1}\right)$, indicative that that $8-\mathrm{H}^{2}$ is cis to $7-\mathrm{H}$. Thus, $8 \mathrm{a}-\mathrm{H}$ and $7-\mathrm{H}$ should be trans to each other, as it holds for exo-adducts.

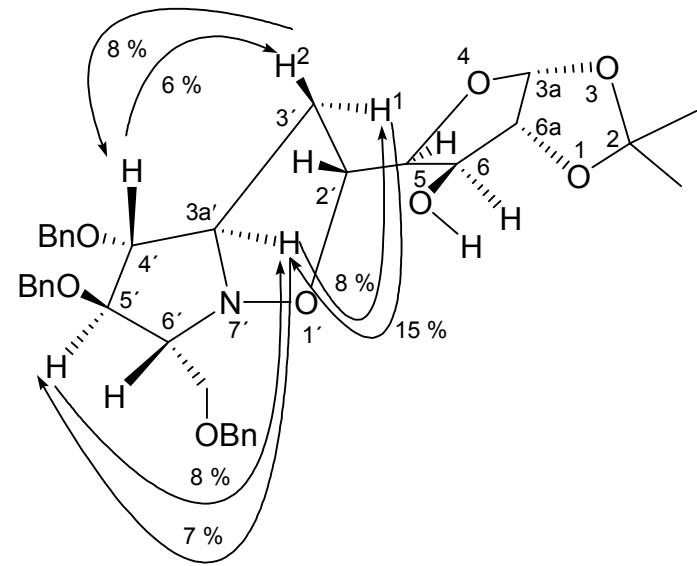

8

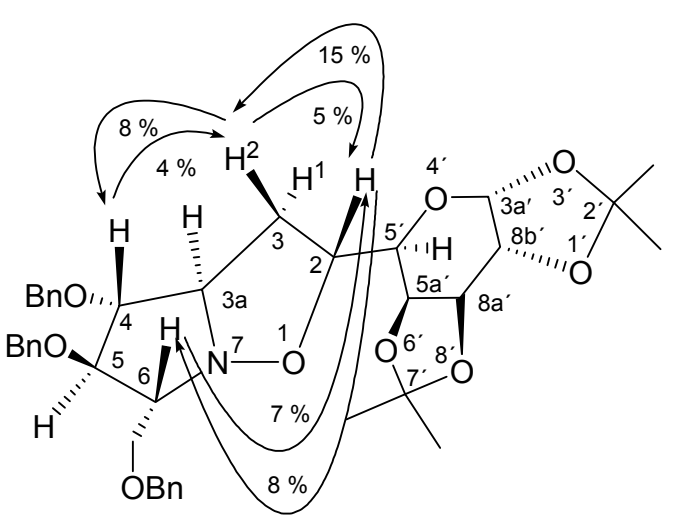

10

Figure 1. NOE enhancements measured on compounds 8 and $\mathbf{1 0 .}$ 
The assigned stereochemistries are also in line with the well documented behavior of cyclic nitrones to react in most cases preferentially via exo transition states ${ }^{12}$ and with our previous results on the reactions of nitrones 6 and 7 with other dipolarophiles. ${ }^{8 b, 10}$ In particular, it has been proved that nitrones $\mathbf{6}$ and $\mathbf{7}$ give Re-exo cycloadducts as major products and $\mathrm{Si}$-exo as minor ones. Nitrone 6 having a more restricted Si-face, since substituents in both 3- and 5positions are oriented towards this face, is more diastereoselective and give higher ratios of the major Re-exo adducts or give them as sole products in the case of more bulky substituents. In nitrone 7 the acetonide moiety lying towards the $S i$-face induces selectivity to the $R e$-face. However, the methoxycarboxy methylene group at the 5-position being in this face near the reaction center reduces the face selectivity so that both Re-exo and Si-exo adducts are obtained. Based on the known behavior of nitrone 7 we propose structures 14a (Re-exo cycloadduct) and 14b (Si-exo cycloadduct) for the obtained unseparable diastereoisomers from the reaction of nitrone 7 with alkene $\mathbf{5}$.

Contrary to the behavior of nitrone 7 with the D-galactose derived alkene $\mathbf{5}$ and also with other alkenes, ${ }^{8 b}$ its reaction with the D-glucose derived alkene $\mathbf{4}$ exhibits high diastereoselectivity and the diastereoisomer from the Re-exo approach is exclusively formed. This behavior is nicely explained by examination of molecular models. Thus, it becomes obvious that in the transition state of the Re-exo approach leading to a ladle shaped tricyclic skeleton, the free hydroxy group of the sugar moiety being in the same site of ester group of nitrone can form a hydrogen bond with the carbonyl oxygen stabilizing this transition state (Scheme 3).

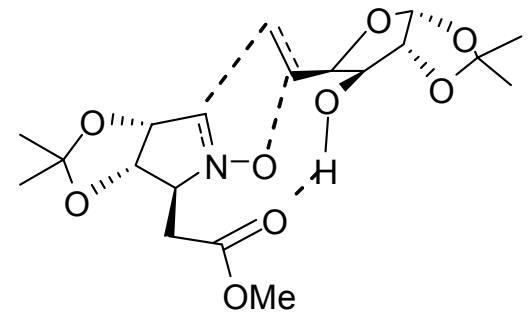

Scheme 3. Re-exo transition state for the formation of compound $\mathbf{1 2 .}$

\section{Conclusions}

1,3-Dipolar cycloadditons of cyclic sugar derived nitrones with sugar derived alkenes can lead conveniently and in high yields to aza- $C$-disaccharides. The diastereoselectivity of the reactions is controlled by the substitution pattern of both the nitrone and the alkene. The preferred stereochemical process is governed by steric factors and comes from the less hindered Re-exo transition state whereas stereoisomers from the Si-exo transition state can be also formed in the case of the less hindered nitrone 7 . However, the formation of an hydrogen bond between the 
free hydroxyl of the alkene and the carbonyl of nitrone enhances diastereoselectivity and give Re-exo adduct as the sole product even in the case of nitrone 7.

\section{Experimental Section}

General Procedures. Mps are uncorrected and were determined on a Kofler hot-stage microscope. IR spectra were recorded on a Perkin-Elmer 297 spectrometer. ${ }^{1} \mathrm{H}$ NMR spectra were recorded at $300 \mathrm{MHz}$ on a Bruker $300 \mathrm{AM}$ spectrometer and ${ }^{13} \mathrm{C}$ NMR spectra at $75.5 \mathrm{MHz}$ on the same spectrometer, and are quoted relative to tetramethylsilane as internal reference, in deuteriochloroform solutions, unless otherwise stated. High resolution mass spectra (HRESI) were obtained with a $7 \mathrm{~T}$ APEX II spectrometer. Elemental analyses were performed with a Perkin-Elmer CHN 2400 automatic analyzer. Optical rotations were measured with a A. KRÜSS Optronic P3002, operating at $589 \mathrm{~nm}\left(1=1 \mathrm{dm}, 25^{\circ} \mathrm{C}\right)$. Column chromatography was carried out on Merck Kieselgel (particle size 0.063-0.200 mm) and solvents were distilled before use.

\section{General procedure for the cycloaddition reactions}

A solution of the nitrone 6 or $7(0.5 \mathrm{mmol})$ and the dipolarophile 4 or $5(0.5 \mathrm{mmol})$ in dry dichloromethane $(5 \mathrm{ml})$ was heated to reflux under an argon atmosphere and the reaction was monitored by TLC until the consumption of the starting reagents. This took about three to four days. Then the heating was stopped and after evaporation of the solvent the residue was chromatographed on a silica gel column with hexane-ethyl acetate 3:1 (for the reactions of nitrone 6), hexane-ethyl acetate $2: 1$ (for the reactions of nitrone 7 ), as the eluents.

(3a $\left.R, 5 S, 6 S, 6 a^{\prime} R\right)-5-\left\{\left(2^{\prime} R, 3 a^{\prime} R, 4^{\prime} R, 5^{\prime} R, 6^{\prime} R\right)-4^{\prime}, 5^{\prime}\right.$-Bis(benzyloxy)-6'-[(benzyloxy) methyl] hexahydropyrrolo[1,2-b]isoxazol-2'-yl\}-2,2-dimethyltetrahydrofuro[2,3- $d][1,3]$ dioxol-6-ol

(8). $80 \%$ Yield as a white solid $\mathrm{mp} 118-120^{\circ} \mathrm{C}$; $[\mathrm{a}]_{D}^{25} \quad-26.5\left(c 0.58, \mathrm{CHCl}_{3}\right) ; \operatorname{Rf} 0.14$ (hexaneethyl acetate 1:1); IR (KBr): $v_{\max } 3414$ (broad), 1619, 1497, 1372, 1319, 1287, 1220,1162,1074 $\mathrm{cm}^{-1}$; ${ }^{1} \mathrm{H}$ NMR: $\delta 1.30\left(\mathrm{~s}, 3 \mathrm{H}, \mathrm{CH}_{3}\right), 1.47\left(\mathrm{~s}, 3 \mathrm{H}, \mathrm{CH}_{3}\right), 2.32\left(\mathrm{ddd}, J=12.8,8.2,5.4 \mathrm{~Hz}, 1 \mathrm{H}, 3^{\prime}-\right.$ $\mathrm{H}), 2.45$ (ddd, $\left.J=12.8,7.7,4.1 \mathrm{~Hz}, 1 \mathrm{H}, 3^{\prime}-\mathrm{H}\right), 3.51-3.61\left(\mathrm{~m}, 3 \mathrm{H}, 6^{\prime}-\mathrm{H}\right.$ and $\left.\mathrm{CH}_{2} \mathrm{OCH}_{2} \mathrm{Ph}\right), 3.75$ (ddd, $\left.J=8.2,5.4,4.1 \mathrm{~Hz}, 1 \mathrm{H}, 3 \mathrm{a}^{\prime}-\mathrm{H}\right), 3.97$ (dd, $\left.J=5.6,2.4 \mathrm{~Hz}, 1 \mathrm{H}, 5-\mathrm{H}\right), 4.04$ (t, J = 4.7 Hz, $\left.1 \mathrm{H}, 4^{\prime}-\mathrm{H}\right), 4.12$ (t, $\left.J=4.7 \mathrm{~Hz}, 1 \mathrm{H}, 5^{\prime}-\mathrm{H}\right), 4.23$ (d, $\left.J=2.4 \mathrm{~Hz}, 1 \mathrm{H}, 6-\mathrm{H}\right), 4.45-4.65$ ( m, 8H, 2', 6a and $\left.\mathrm{PhCH}_{2} \mathrm{O}\right), 4.9$ (br, $\left.1 \mathrm{H}, \mathrm{OH}\right), 5.96(\mathrm{~d}, J=3.7 \mathrm{~Hz}, 1 \mathrm{H}, 3 \mathrm{a}-\mathrm{H}), 7.20-7.40(\mathrm{~m}, 15 \mathrm{H}, \mathrm{Ph}-\mathrm{H}) ;{ }^{13} \mathrm{C}$ NMR: $\delta 26.1$ and $26.7\left(\mathrm{CH}_{3}\right), 37.0\left(\mathrm{C}-3^{\prime}\right), 67.7,69.6,69.8,72.1,72.2,73.3,73.8,74.7,81.4$, 84.9, 85.1 and 88.2 (C-5, C-6, C-6a, C-2', C-3a', C-4', C-5', C-6', $\mathrm{CH}_{2} \mathrm{O}$ and $\mathrm{PhCH}_{2} \mathrm{O}$ ), 104.9

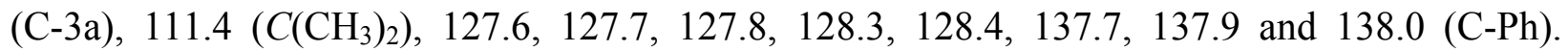
HRESIMS for $\mathrm{C}_{35} \mathrm{H}_{42} \mathrm{NO}_{8}(\mathrm{M}+\mathrm{H})^{+}$calcd 604.2910, found 604.2906. Anal. Calcd. for $\mathrm{C}_{35} \mathrm{H}_{41} \mathrm{NO}_{8}$ : C, 69.63; H, 6.85; N, 2.32. Found: C, 69.33; H, 6.99; N, 2.13. 


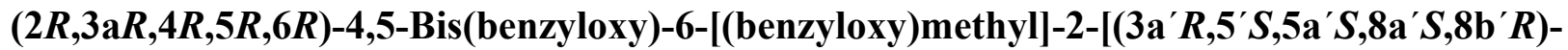
$2^{\prime}, 2^{\prime}, 7^{\prime}, 7^{\prime}$-tetramethyltetrahydro-3a' $H$-bis $[1,3]$ dioxolo $\left[4,5-b: 4^{\prime}, 5^{\prime}-d\right]$ pyran-5'-

yl]hexahydropyrrolo[1,2-b]isoxazole (10). 82\% Yield as an oil. [a $]_{D}^{25}-73.0$ (c 2.2, $\mathrm{CHCl}_{3}$ ); $R f$ 0.45 (hexane-ethyl acetate 2:1); IR (film): $v_{\max } 1607,1497,1454,1383,1256,1211,1109,1070$ $\mathrm{cm}^{-1}$; ${ }^{1} \mathrm{H}$ NMR: $\delta 1.31\left(\mathrm{~s}, 3 \mathrm{H}, \mathrm{CH}_{3}\right), 1.33\left(\mathrm{~s}, 3 \mathrm{H}, \mathrm{CH}_{3}\right), 1.43\left(\mathrm{~s}, 3 \mathrm{H}, \mathrm{CH}_{3}\right), 1.49\left(\mathrm{~s}, 3 \mathrm{H}, \mathrm{CH}_{3}\right)$, 2.29-2.48 (m, 2H, 3-H), 3.35 (br q , $J \approx 5.4 \mathrm{~Hz}, 1 \mathrm{H}, 6-\mathrm{H}), 3.62-3.80\left(\mathrm{~m}, 4 \mathrm{H}, 3 \mathrm{a}, 5{ }^{\prime}-\mathrm{H}\right.$ and $\left.\mathrm{CH}_{2} \mathrm{OCH}_{2} \mathrm{Ph}\right), 4.01(\mathrm{t}, J=4.3 \mathrm{~Hz}, 1 \mathrm{H}, 4-\mathrm{H}), 4.07(\mathrm{dd}, J=6.7,4.3 \mathrm{~Hz}, 1 \mathrm{H}, 5-\mathrm{H}), 4.27(\mathrm{dd}, J=$ 4.9, $\left.2.4 \mathrm{~Hz}, 1 \mathrm{H}, 8 \mathrm{~b}^{\prime}-\mathrm{H}\right), 4.28-4.45\left(\mathrm{~m}, 2 \mathrm{H}, 2-\mathrm{H}\right.$ and $\left.5 \mathrm{a}^{\prime}-\mathrm{H}\right), 4.45-4.70\left(\mathrm{~m}, 7 \mathrm{H}, 8 \mathrm{a}^{\prime}-\mathrm{H}\right.$ and $\left.\mathrm{PhCH}_{2} \mathrm{O}\right), 5.52\left(\mathrm{~d}, J=4.9 \mathrm{~Hz}, 1 \mathrm{H}, 3 \mathrm{a}^{\prime}-\mathrm{H}\right), 7.19-7.38(\mathrm{~m}, 15 \mathrm{H}, \mathrm{Ph}-\mathrm{H}) ;{ }^{1} \mathrm{H}$ NMR $\left(\mathrm{CDCl}_{3} / \mathrm{C}_{6} \mathrm{D}_{6}\right.$ 1/2): $\delta 1.10\left(\mathrm{~s}, 3 \mathrm{H}, \mathrm{CH}_{3}\right), 1.19\left(\mathrm{~s}, 3 \mathrm{H}, \mathrm{CH}_{3}\right), 1.42\left(\mathrm{~s}, 3 \mathrm{H}, \mathrm{CH}_{3}\right), 1.44\left(\mathrm{~s}, 3 \mathrm{H}, \mathrm{CH}_{3}\right), 2.34(\mathrm{dt}, J=$ $12.7,6.6 \mathrm{~Hz}, 1 \mathrm{H}, 3-\mathrm{H}), 2.51$ (ddd, $J=12.7,9.2,4.8 \mathrm{~Hz}, 1 \mathrm{H}, 3-\mathrm{H}), 3.45$ (br q , $J \approx 5.4 \mathrm{~Hz}, 1 \mathrm{H}, 6-$ $\mathrm{H}), 3.59-3.72\left(\mathrm{~m}, 2 \mathrm{H}, \mathrm{CH}_{2} \mathrm{OCH}_{2} \mathrm{Ph}\right), 3.75-3.85\left(\mathrm{~m}, 2 \mathrm{H}, 3 \mathrm{a}-\mathrm{H}\right.$ and $\left.5^{\prime}-\mathrm{H}\right), 3.90(\mathrm{t}, J=4.0 \mathrm{~Hz}, 1 \mathrm{H}$,

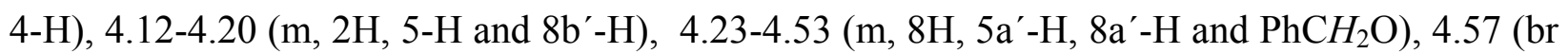
q $\Sigma J=19.6 \mathrm{~Hz}, 1 \mathrm{H}, 2-\mathrm{H}), 5.43\left(\mathrm{~d}, J=4.9 \mathrm{~Hz}, 1 \mathrm{H}, 3 \mathrm{a}^{\prime}-\mathrm{H}\right), 7.05-7.29(\mathrm{~m}, 15 \mathrm{H}, \mathrm{Ph}-\mathrm{H}) ;{ }^{13} \mathrm{C}$ NMR: $\delta$ 24.3, 24.925 .8 and $26.0\left(\mathrm{CH}_{3}\right), 32.4(\mathrm{C}-3), 58.9,60.9,68.0,68.3,68.6,70.3,70.6,70.7,71.2$, 72.0, 73.0, 85.6 and 89.0 (C-2, C-3a, C-4, C-5, C-6, C-5', C-5a', C-8a', C-8b', $\mathrm{CH}_{2} \mathrm{O}$ and

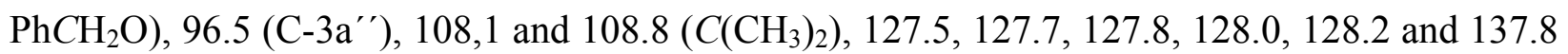
(C-Ph). HRESIMS for $\mathrm{C}_{39} \mathrm{H}_{48} \mathrm{NO}_{9}(\mathrm{M}+\mathrm{H})^{+}$calcd 674.3329, found 674.3327. Anal. Calcd. for $\mathrm{C}_{39} \mathrm{H}_{47} \mathrm{NO}_{9}$ : C, 69.52; H, 7.03; N, 2.08. Found: C, 69.33; H, 6.95; N, 2.17.

Methyl $\quad\left\{(3 \mathrm{a} S, 4 S, 7 R, 8 \mathrm{a} R, 8 \mathrm{~b} R)-7-\left[\left(3 \mathrm{a}^{\prime} R, 5^{\prime} S, 6^{\prime} S, 6 \mathrm{a}^{\prime} R\right)-6^{\prime}\right.\right.$-hydroxy-2',2'-dimethyltetra hydrofuro[2,3- $d][1,3]$ dioxol-5' - yl]-2,2-dimethylhexahydro[1,3]dioxolo[3,4]pyrrolo [1,2b]isoxazol-4-yl\}acetate (12). $85 \%$ Yield as a white solid mp 140-142 ${ }^{\circ} \mathrm{C}$; $[\mathrm{a}]_{D}^{25}+60.0(c 0.41$, $\mathrm{CHCl}_{3}$ ); Rf 0.22 (hexane-ethyl acetate 1:1); IR (KBr): $v_{\max } 3472,1739,1382,1213,1164,1074$ $\mathrm{cm}^{-1} ;{ }^{1} \mathrm{H}$ NMR $\left(\mathrm{CDCl}_{3} / \mathrm{C}_{6} \mathrm{D}_{6} 3 / 1\right): \delta 1.29\left(\mathrm{~s}, 6 \mathrm{H}, \mathrm{CH}_{3}\right), 1.46\left(\mathrm{~s}, 3 \mathrm{H}, \mathrm{CH}_{3}\right), 1.50\left(\mathrm{~s}, 3 \mathrm{H}, \mathrm{CH}_{3}\right), 2.39$ (ddd, $J=13.0,8.0,5.8 \mathrm{~Hz}, 1 \mathrm{H}, 8-\mathrm{H}), 2.56(\mathrm{dd}, J=13.0,8.9,1 \mathrm{H}, 8-\mathrm{H}), 2.74$ (dd, $J=15.1,5.8$ $\mathrm{Hz}, 1 \mathrm{H}, \mathrm{CH}_{2} \mathrm{CO}_{2} \mathrm{CH}_{3}$ ), 2.91 (dd, $J=15.1,9.0 \mathrm{~Hz}, 1 \mathrm{H}, \mathrm{CH}_{2} \mathrm{CO}_{2} \mathrm{CH}_{3}$ ), 3.67 (overlapped s and $\mathrm{m}$, $4 \mathrm{H}, \mathrm{CO}_{2} \mathrm{CH}_{3}$ and $\left.4-\mathrm{H}\right), 3.82(\mathrm{dd}, J=8.0,2.4 \mathrm{~Hz}, 1 \mathrm{H}, 8 \mathrm{a}-\mathrm{H}), 3.88\left(\mathrm{dd}, J=4.5,2.6 \mathrm{~Hz}, 1 \mathrm{H}, 6^{\prime}-\mathrm{H}\right)$, $4.19\left(\mathrm{~d}, J=2.6 \mathrm{~Hz}, 1 \mathrm{H}, 5^{\prime}-\mathrm{H}\right), 4.46-4.58\left(\mathrm{~m}, 3 \mathrm{H}, 7-\mathrm{H}, 8 \mathrm{~b}-\mathrm{H}\right.$ and $\left.6 \mathrm{a}^{\prime}-\mathrm{H}\right), 4.68(\mathrm{t}, J=6.2 \mathrm{~Hz}, 1 \mathrm{H}$, $3 \mathrm{a}-\mathrm{H}), 4.83$ (br, 1H, OH), $5.93\left(\mathrm{~d}, J=3.9 \mathrm{~Hz}, 1 \mathrm{H}, 3 \mathrm{a}^{\prime}-\mathrm{H}\right) ;{ }^{13} \mathrm{C}$ NMR: $\delta 25.1,26.0,26.7$ and 27.4 $\left(\mathrm{CH}_{3}\right), 34.0$ and $37.0\left(\mathrm{C}-8\right.$ and $\left.\mathrm{CH}_{2} \mathrm{CO}_{2} \mathrm{CH}_{3}\right), 51.9\left(\mathrm{OCH}_{3}\right), 69.1,70.4,73.0,75.0,81.7,85.1$, 85.3, 87.6 (C-3a, C-4, C-7, C-8a, C-8b, C-5', C-6', C-6a'), 104.7 (C-3a'), 111.3 and 115.1 $\left(C\left(\mathrm{CH}_{3}\right)_{2}\right), 171.4(\mathrm{CO})$. HRESIMS for $\mathrm{C}_{19} \mathrm{H}_{30} \mathrm{NO}_{9}(\mathrm{M}+\mathrm{H})^{+}$calcd 416.1920, found 416.1917. Anal. Calcd. for $\mathrm{C}_{19} \mathrm{H}_{29} \mathrm{NO}_{9}$ : C, 54.93; H, 7.04; N, 3.37. Found: C, 54.75; H, 7.02; N, 3.24.

Methyl $\quad\left\{(3 \mathrm{a} S, 4 S, 7 R, 8 \mathrm{a} R, 8 \mathrm{~b} R)-2,2-d i m e t h y l-7-\left[\left(3 \mathrm{a}^{\prime} R, 5^{\prime} S, 5 \mathrm{a}^{\prime} S, 8 \mathrm{a}^{\prime} S, 8 \mathrm{~b}^{\prime} R\right)-2^{\prime}, 2^{\prime}, 7^{\prime}, 7^{\prime}-\right.\right.$ tetramethyltetrahydro-3a' $H$-bis $[1,3]$ dioxolo $\left[4,5-b: 4^{\prime}, 5^{\prime}-d\right]$ pyran-5'-yl]hexahydro[1,3] dioxolo[3,4]pyrrolo[1,2-b]isoxazol-4-yl\}acetate (14a) and methyl $\{(3 \mathrm{a} S, 4 S, 7 S, 8 \mathrm{a} S, 8 \mathrm{~b} R)-2,2-$ dimethyl-7-[(3a' $\left.R, 5^{\prime} S, 5 a^{\prime} S, 8 a^{\prime} S, 8 b^{\prime} R\right)-2^{\prime}, 2^{\prime}, 7^{\prime}, 7^{\prime}$-tetra methyltetrahydro-3a' $H$-bis $[1,3]$ dioxolo[4,5- $\left.b: 4^{\prime}, 5 '-d\right]$ pyran-5'-yl]hexahydro[1,3] dioxolo[3,4]pyrrolo[1,2-b]isoxazol-4yl acetate (14b). Obtained as a mixture in a ratio $3: 2$ and $85 \%$ total yield. $R f 0.4$ (hexane-ethyl acetate 1:1); ${ }^{1} \mathrm{H}$ NMR: $\delta$ 1.25, 1.31, 1.34, 1.44, 1.49, 1.51 and $1.53\left(\mathrm{~s}, \mathrm{CH}_{3}\right), 2.27$ (ddd, $J=$ 
14.2, 7.1, 5.1 Hz, one of 8- $\mathrm{H}$ of the major isomer), 2.38-2.79 (m, 8- $\mathrm{H}$ and $\left.\mathrm{CH}_{2} \mathrm{CO}_{2} \mathrm{CH}_{3}\right), 3.01$ (dd, $J=16.1,8.3 \mathrm{~Hz}$, one of the $\mathrm{CH}_{2} \mathrm{CO}_{2} \mathrm{CH}_{3}$ of the minor isomer), 3.60-3.85 (overlapped $\mathrm{s}$ and

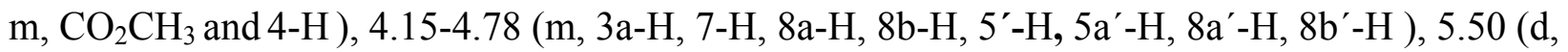
$J=5.0 \mathrm{~Hz}, 3 \mathrm{a}^{\prime}-\mathrm{H}$ of the major isomer), $5.53\left(\mathrm{~d}, J=5.0 \mathrm{~Hz}, 3 \mathrm{a}^{\prime}-\mathrm{H}\right.$ of the minor isomer). ${ }^{13} \mathrm{C}$ NMR: $\delta$ 24.3, 24.5, 24.6, 25.0, 25.1, 25.9, 26.0, 26.1, 26.4, 26.8, 27.4 and 29.6 $\left(\mathrm{CH}_{3}\right), 32.9,34.2$, 35.6 and $37.1\left(\mathrm{C}-8\right.$ and $\left.\mathrm{CH}_{2} \mathrm{CO}_{2} \mathrm{CH}_{3}\right), 51.6$ and $51.7\left(\mathrm{OCH}_{3}\right), 66.7,67.1,68.6,69.0,69.2,70.3$, 70.4, 70.5, 70.6, 70.8, 71.1, 75.5, 76.2, 77.2, 79.6, 84.6, 86.0 and 87.9 (C-3a, C-4, C-7, C-8a, C8b, C-5', C-5a', C-8a' and C-8b'), 96.2 and 96.4 (C-3a'), 108.5, 108.8, 109.0, 109.5, 111.3 and $114.7\left(\mathrm{C}\left(\mathrm{CH}_{3}\right)_{2}\right), 171.4$ and 171.8(CO). HRESIMS for $\mathrm{C}_{23} \mathrm{H}_{35} \mathrm{NO}_{10}(\mathrm{M})^{+}$calcd 485.2261, found 485.2255. Anal. Calcd. for $\mathrm{C}_{23} \mathrm{H}_{35} \mathrm{NO}_{10}$ : C, 56.90; H, 7.27; N, 2.88. Found: C, 56.75; H, 7.12; N, 2.64 .

\section{General procedure for the isoxazolidine reduction reactions}

A catalytic amount of Raney Ni (about $20 \mathrm{mg}$ ) was added to a previously degassed solution of isoxazolidine $(0.5 \mathrm{mmol})$ in $\mathrm{MeOH}(5 \mathrm{~mL})$ under a hydrogen atmosphere (balloon). The mixture was stirred for about 2 days and then the crude reaction mixture was passed through Celite, concentrated and purified by column chromatography on silica gel using ethyl acetate as the eluent.

6- $\left\{\left(2^{\prime} R, 3^{\prime} R, 4^{\prime} R, 5^{\prime} R\right)-3^{\prime}, 4^{\prime}\right.$-Bis(benzyloxy)-5' -[(benzyloxy)methyl]pyrrolidin-2'-yl\}-6-deoxy1,2-O-(1-methylethylidene)- $\alpha$-D-glucofuranose (9). Yield $90 \%$ as a white solid mp 145-147 ${ }^{\circ} \mathrm{C}$; $[\mathrm{a}]_{D}^{25}-18.3$ (c 0.41, $\mathrm{CHCl}_{3}$ ); Rf 0.2 (ethyl acetate); IR (KBr): $v_{\max } 3313$ (broad), 1455, 1372, 1214, 1165, 1074, $1016 \mathrm{~cm}^{-1}$; ${ }^{1} \mathrm{H}$ NMR: $\delta 1.32\left(\mathrm{~s}, 3 \mathrm{H}, \mathrm{CH}_{3}\right), 1.48\left(\mathrm{~s}, 3 \mathrm{H}, \mathrm{CH}_{3}\right), 1.79(\mathrm{ddd}, J=$ 14.4, 8.6, 4.3 Hz, 1H, 6-H), 1.92 (ddd, $J=14.4,7.0,2.4$ Hz, 1H, 6-H), 3.33-3.40 (br m, 1H, 5'$\mathrm{H})$, 3.46-3.52 (m, 2H, $\mathrm{CH}_{2} \mathrm{OCH}_{2} \mathrm{Ph}$ ), 3.53-3.61 (br m, 1H, 2'-H), 3.88-3.93 (m, 2H, 3'-H and 4' H), $3.97(\mathrm{dd}, J=5.7,2.6 \mathrm{~Hz}, 1 \mathrm{H}, 4-\mathrm{H}), 4.26(\mathrm{ddd}, J=8.6,6.1,4 \mathrm{~Hz}, 1 \mathrm{H}, 5-\mathrm{H}), 4.33(\mathrm{~d}, J=2.6$ $\mathrm{Hz}, 1 \mathrm{H}, 3-\mathrm{H}), 4.43-4.58$ ( $\mathrm{m}, 7 \mathrm{H}, 2-\mathrm{H}$ and $\mathrm{PhCH}_{2} \mathrm{O}$ ), 5.96 (d, $\left.J=3.7 \mathrm{~Hz}, 1 \mathrm{H}, 1-\mathrm{H}\right), 7.20-7.40$ (m, 15H, Ph-H); ${ }^{13} \mathrm{C}$ NMR: $\delta 26.2$ and $26.9\left(\mathrm{CH}_{3}\right), 33.2(\mathrm{C}-6), 59.5,61.1,69.0,69.2,72.1,73.2$, 75.7, 76.5, 81.6, 84.9, 85.3 and 87.3 (C-2, C-3, C-4, C-5, C-2', C-3', C-4', C-5', $\mathrm{CH}_{2} \mathrm{O}$ and

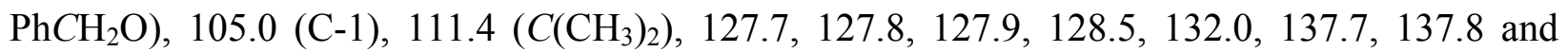
137.9 (C-Ph). HRESIMS for $\mathrm{C}_{35} \mathrm{H}_{44} \mathrm{NO}_{8}(\mathrm{M}+\mathrm{H})^{+}$calcd 606.3067, found 606.3063. Anal. Calcd. for $\mathrm{C}_{35} \mathrm{H}_{43} \mathrm{NO}_{8}$ : C, 69.40; H, 7.16; N, 2.31. Found: C, 69.22; H, 7.05; N, 2.10.

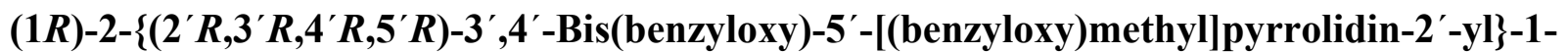
$\left[\left(3 a^{\prime \prime} R, 5^{\prime \prime} R, 5 a^{\prime \prime} S, 8 a^{\prime \prime} S, 8 b^{\prime \prime} R\right)-2^{\prime \prime}, 2^{\prime \prime}, 7^{\prime \prime}, 7^{\prime \prime}\right.$-tetramethyltetrahydro-3a' $H$-bis[1,3]dioxolo [4,5-b:4',5'-d]pyran-5' -yl]ethanol (11). Yield $92 \%$ as an oil; $[\mathrm{a}]_{D}^{25}-36.9\left(c\right.$ 1.9, $\left.\mathrm{CHCl}_{3}\right) ; R f 0.3$ (ethyl acetate); IR (film): $v_{\max } 3400$ (broad), 1454, 1382, 1255, 1210, 1168, $1066 \mathrm{~cm}^{-1}$; ${ }^{1} \mathrm{H}$ NMR: $\delta 1.31\left(\mathrm{~s}, 3 \mathrm{H}, \mathrm{CH}_{3}\right), 1.36\left(\mathrm{~s}, 3 \mathrm{H}, \mathrm{CH}_{3}\right), 1.45\left(\mathrm{~s}, 3 \mathrm{H}, \mathrm{CH}_{3}\right), 1.47$ (s, 3H, $\left.\mathrm{CH}_{3}\right), 1.80$ (dt, J=14.3, $4.3 \mathrm{~Hz}, 1 \mathrm{H}, 2-\mathrm{H}), 2.51$ (ddd, $J=14.3,10.7,3.2 \mathrm{~Hz}, 1 \mathrm{H}, 2-\mathrm{H}), 3.35$ (br q, $\Sigma J=15.0 \mathrm{~Hz}, 1 \mathrm{H}, 5^{\prime}-$ $\mathrm{H}), 3.54\left(\mathrm{~d}, \mathrm{~J}=3.9 \mathrm{~Hz}, 2 \mathrm{H}, \mathrm{CH}_{2} \mathrm{OCH}_{2} \mathrm{Ph}\right), 3.63-3.73\left(\mathrm{~m}, 2 \mathrm{H}, 2^{\prime}\right.$ and $\left.5^{\prime \prime} \mathrm{H}\right), 3.83(\mathrm{t}, \mathrm{J}=3.2 \mathrm{~Hz}$, $\left.1 \mathrm{H}, 3^{\prime}-\mathrm{H}\right), 3.94\left(\mathrm{dd}, J=5.8,3.2 \mathrm{~Hz}, 1 \mathrm{H}, 4^{\prime}-\mathrm{H}\right), 4.03-4.11(\mathrm{~m}, 1 \mathrm{H}, 1-\mathrm{H}), 4.31(\mathrm{dd}, J=4.8,1.9 \mathrm{~Hz}$, 
$\left.1 \mathrm{H}, 8 \mathrm{a}^{\prime \prime}-\mathrm{H}\right), 4.41-4.66\left(\mathrm{~m}, 8 \mathrm{H}, 5 \mathrm{a}^{\prime \prime}, 8 \mathrm{~b}^{\prime \prime}-\mathrm{H}\right.$ and $\left.\mathrm{PhCH} \mathrm{H}_{2} \mathrm{O}\right), 5.56\left(\mathrm{~d}, J=4.8 \mathrm{~Hz}, 1 \mathrm{H}, 3 \mathrm{a}^{\prime \prime}-\mathrm{H}\right)$, 7.10-7.38 (m, 15H, Ph-H); ${ }^{13} \mathrm{C}$ NMR: $\delta$ 24.2, 24.8, 25.8 and $26.0\left(\mathrm{CH}_{3}\right), 37.5(\mathrm{C}-2), 67.5,68.4$, 69.7, 69.9, 70.4, 70.6, 70.7, 71.7, 72.2, 73.2, 74.6, 83.9 and 87.1 (C-1, C-2', C-3', C-4', C-5', C-

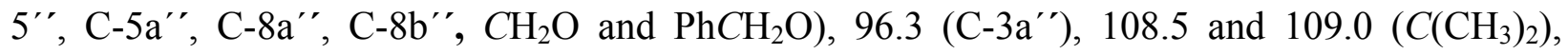
127.3, 127.5, 127.6, 128.1, 128.2, 128.3, 137.7, 138.1 and 138.4 (C-Ph). HRESIMS for $\mathrm{C}_{39} \mathrm{H}_{49} \mathrm{NO}_{9} \mathrm{Na}(\mathrm{M}+\mathrm{Na})^{+}$calcd 698.3305, found 698.3313. Anal. Calcd. for $\mathrm{C}_{39} \mathrm{H}_{47} \mathrm{NO}_{9}$ : C, 69.31; H, 7.31; N, 2.07. Found: C, 69.32; H, 7.40; N, 2.02.

6-Deoxy-6-[(3a' $\left.R, 4^{\prime} R, 6^{\prime} S, 6 a^{\prime} S\right)-6-\left(2^{\prime \prime}\right.$-methoxy-2"'-oxoethyl)-2',2'-dimethyl tetrahydro3a' $H$-[1,3]dioxolo[4,5-c]pyrrol-4-yl]-1,2- $O$-(1-methylethylidene)- $\alpha$-D-glucofuranose (13). Yield $92 \%$ as an oil. $[\mathrm{a}]_{D}^{25}+77.0\left(c 0.25, \mathrm{CHCl}_{3}\right) ; \operatorname{Rf} 0.1$ (hexane-ethyl acetate 1:1); IR (film): $v_{\max } 3444$ (broad), 1732, 1439, 1373, 1213, 1163, 1072, $1015 \mathrm{~cm}^{-1} ;{ }^{1} \mathrm{H}$ NMR: $\delta 1.31$ (s, 6H, $\left.\mathrm{CH}_{3}\right), 1.47$ (s, 3H, $\left.\mathrm{CH}_{3}\right), 1.50\left(\mathrm{~s}, 3 \mathrm{H}, \mathrm{CH}_{3}\right), 1.92$ (t, $\left.J=5.4 \mathrm{~Hz}, 2 \mathrm{H}, 6-\mathrm{H}\right), 2.44$ (dd, $J=16.7,9.6$ $\left.\mathrm{Hz}, 1 \mathrm{H}, \mathrm{CH}_{2} \mathrm{CO}_{2} \mathrm{CH}_{3}\right), 2.77\left(\mathrm{dd}, J=16.7,3.9 \mathrm{~Hz}, 1 \mathrm{H}, \mathrm{CH}_{2} \mathrm{CO}_{2} \mathrm{CH}_{3}\right), 3.42$ (dt, $J=7.8,5.4 \mathrm{~Hz}$, $1 \mathrm{H}, 5-\mathrm{H}), 3.61$ (dd, $\left.J=9.6,3.9 \mathrm{~Hz}, 1 \mathrm{H}, 6^{\prime}-\mathrm{H}\right), 3.69$ (s, 3H, $\mathrm{OCH}_{3}$ ), 3.83 (br, 2H, OH), 3.94 (dd, $\left.J=5.4,2.7 \mathrm{~Hz}, 1 \mathrm{H}, 4^{\prime}-\mathrm{H}\right), 4.25-4.35$ (m, 3H, 2-H, 3-H, 4-H), 4.47-4.54 (m, 2H, 3a'-H, 6a' -H), $5.95(\mathrm{~d}, J=3.9 \mathrm{~Hz}, 1 \mathrm{H}, 1-\mathrm{H}) ;{ }^{13} \mathrm{C}$ NMR: $\delta$ 25.3, 26.1, 26.8 and $27.4\left(\mathrm{CH}_{3}\right), 35.0$ and $38.2(\mathrm{C}-6$ and $\left.\mathrm{CH}_{2} \mathrm{CO}_{2} \mathrm{CH}_{3}\right), 51.8\left(\mathrm{OCH}_{3}\right), 60.1,61.7,70.0,75.4,81.9,82.9,83.8,85.3(\mathrm{C}-2, \mathrm{C}-3, \mathrm{C}-4, \mathrm{C}-$ 5, C-3a', C-4', C-6', C-6a'), 104.9 (C-1), 111.4 and $113.9\left(C\left(\mathrm{CH}_{3}\right)_{2}\right), 172.2(\mathrm{CO})$. HRESIMS for $\mathrm{C}_{19} \mathrm{H}_{32} \mathrm{NO}_{9}(\mathrm{M}+\mathrm{H})^{+}$calcd 418.2077 found 418.2070. Anal. Calcd. for $\mathrm{C}_{19} \mathrm{H}_{31} \mathrm{NO}_{9}$ : C, 54.67; $\mathrm{H}$, 7.48; N, 3.36. Found: C, 54.55; H, 7.32; N, 3.15.

Methyl $\quad\left[(3 a S, 4 S, 6 R, 6 a R)-6-\left\{(2 ' R)-2\right.\right.$ '-hydroxy-2'-[(3a'"R,5" $\left.R, 5 a^{\prime \prime} S, 8 a^{\prime \prime} S, 8 b^{\prime \prime} R\right)-$ $2^{\prime \prime}, 2^{\prime \prime}, 7^{\prime \prime}, 7^{\prime \prime}$-tetramethyltetrahydro-3a' $H$-bis $[1,3]$ dioxolo $[4,5-b: 4 ', 5 '-d]$ pyran-5"'-yl]ethyl $\}$ 2,2-dimethyltetrahydro-3aH-[1,3]dioxolo[4,5-c]pyrrol-4-yl]acetate (15a) and methyl [(3aS,4S,6S,6aR)-6-\{(2'S)-2'-hydroxy-2'-[(3a' $\left.R, 5^{\prime \prime} R, 5^{\prime \prime} \mathrm{a} S, 8 \mathrm{a}^{\prime \prime} S, 8 \mathrm{~b}^{\prime \prime} R\right)-2^{\prime \prime}, 2^{\prime \prime}, 7^{\prime \prime}, 7^{\prime \prime}$-tetramethyltetrahydro-3a' $H$-bis $[1,3]$ dioxolo[4,5-b:4',5'-d]pyran-5' -yl]ethyl $\}-2,2$-dimethyl-

tetrahydro-3a $\boldsymbol{H}$-[1,3]dioxolo[4,5-c]pyrrol-4-yl]acetate (15b). Obtained as a mixture in a ratio $3: 2$ and $95 \%$ total yield. $R f 0.42$ (ethyl acetate); ${ }^{1} \mathrm{H}$ NMR: $\delta 1.29,1.30,1.33,1.37,1.46,1.149$ and $1.52\left(\mathrm{~s}, \mathrm{CH}_{3}\right), 1.56-2.10\left(\mathrm{~m}, 1^{\prime}-\mathrm{H}\right), 2.36\left(\mathrm{~d}, J=8.5 \mathrm{~Hz}, \mathrm{CH}_{2} \mathrm{CO}_{2} \mathrm{CH}_{3}\right.$ of the major isomer), 2.46 (dd, $J=16.5,9.8 \mathrm{~Hz}$, one of the $\mathrm{CH}_{2} \mathrm{CO}_{2} \mathrm{CH}_{3}$ of the minor isomer), 2.75 (dd, $J=16.5,4.3$ $\mathrm{Hz}$, one of the $\mathrm{CH}_{2} \mathrm{CO}_{2} \mathrm{CH}_{3}$ of the minor isomer), 2.44 (br, $\left.\mathrm{OH}\right), 3.17$ (dt, $J=8.5,4.9 \mathrm{~Hz}, 2^{\prime}-\mathrm{H}$ of the major isomer), 3.39-3.64 (m, $2^{\prime}-\mathrm{H}$ of the minor isomer, 4-H, 6-H), $3.68\left(\mathrm{OCH}_{3}\right.$ of the minor isomer), $3.70\left(\mathrm{OCH}_{3}\right.$ of the major isomer), 3.93-4.14 (m, 5"'-H), 4.23-4.68 (m, 3a-H, 6a-H, 5a"'$\left.\mathrm{H}, 8 \mathrm{a}^{\prime \prime}-\mathrm{H}, 8 \mathrm{~b}^{\prime \prime}-\mathrm{H}\right), 5.52$ (d, $J=4.5 \mathrm{~Hz}, 3 \mathrm{a}^{\prime \prime}-\mathrm{H}$ of the major isomer), 5.62 (dd, $J=4.9 \mathrm{~Hz}, 3 \mathrm{a}^{\prime \prime}-\mathrm{H}$ of the minor isomer); ${ }^{13} \mathrm{C}$ NMR: $\delta$ 23.4, 24.2, 24.3, 24.8, 24.9, 25.3, 25.8, 25.9, 26.0, 27.3 and $29.6\left(\mathrm{CH}_{3}\right), 31.8,35.8,36.2$ and $38.4\left(\mathrm{C}-1^{\prime}\right.$ and $\left.\mathrm{CH}_{2} \mathrm{CO}_{2} \mathrm{CH}_{3}\right), 51.6$ and $51.8\left(\mathrm{OCH}_{3}\right), 57.8,60.2$, $61.1,61.2,67.9,68.9,69.5,69.9,70.5,70.6,70.7,70.9,72.1,82.8,84.1,84.4$ and 85.5 (C-3a, C4, C-6, C-6a, C-2', C-5"', C-5a"', C-8a'" and C-8b' '), 96.5 (C-3a' '), 108.2, 108.6, 109.0, 109.4,

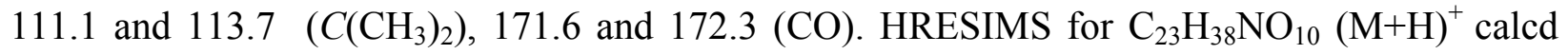
488.2496, found 488.2455. Anal. Calcd. for $\mathrm{C}_{23} \mathrm{H}_{37} \mathrm{NO}_{10}$ : C, 56.66; H, 7.65; N, 2.87. Found: C, 56.29; H, 7.39; N, 2.63. 


\section{References}

1. (a) Iminosugars as Glycosidase Inhibitors: Nojirimycin and Beyond; Stütz, A. F., Ed.; Wiley-VCH: Weinheim, 1999. (b) Carbohydrate Mimics; Chapleur, Y., Ed.; Wiley-VCH: Weinheim, 1998.

2. For a recent review about aza- $C$-disaccharides see: Robina, E.; Vogel, P. Synthesis 2005, 6752.

3. (a) Johnson, C. R.; Miller, M. W.; Golebiowski, A.; Sundram, H.; Ksebati, M. B. Tetrahedron Lett. 1994, 35, 8991. (b) Martin, O. R.; Liu, L.; Yang, F. Tetrahedron Lett. 1996, 37, 1991. (c) Baudat, A.; Vogel, P. Tetrahedron Lett. 1996, 37, 483. (d) Frenot E.; Marquis, C.; Vogel, P. Tetrahedron Lett. 1996, 37, 2023. (e) Johns, B. A.; Pan, Y. T.; Elbein, A. D.; Johnson, C.R. J. Am. Chem. Soc. 1997, 119, 4856. (f) Baudat, A.; Vogel, P. J. Org. Chem. 1997, 62, 6252. (g) Leeuwenburgh, M. A.; Picasso, S.; Overkleeft, H. S.; van der Marel, G. A.; Vogel, P.; van Boom, J. H. Eur. J. Org. Chem. 1999, 1185. (h) Marquis, C.; Picasso; S.; Vogel, P. Synthesis 1999, 1441. (i) Zhu, Y. H.; Vogel, P. Chem. Commun. 1999, 1873. (j) Zhu, Y. H.; Vogel, P. J. Org. Chem. 1999, 64, 666. (k) Dondoni, A.; Giovannini, P. P.; Marra, A. Tetrahedron Lett. 2000, 41, 6195. (1) Vogel, P. Current Organic Chemistry 2000, 4, 455, and references cited therein; (m) Cheng, X.; Kumaran, G.; Mootoo, D. R. Chem. Commun. 2001, 811. (n) Navarro, I.; Vogel, P. Helv. Chim. Acta 2002, 85, 152. (o) Awad, L.; Demange, R.; Zhu, Y-H.; Vogel, P. Carbohydr. Res. 2006, 341, 1235. (p) Zeitouni, J.; Norsikian, S.; Merlet, D.; Lubineau, A. Adv. Synth. Catal. 2006, 348, 1662. (q) Rodríguez-García, E.; Brimble, M.A.; Vogel, P Eur. J. Org. Chem. 2006, 3845 .

4. Argyropoulos, N. G.; Sarli, V. C. Tetrahedron Lett. 2004, 45, 4237.

5. For recent reviews about applications of nitrones in sugar chemistry see: (a) Osborn, H. M. I.; Gemmel, N.; Harwood, L. M. J. Chem. Soc. Perkin Trans. 1 2002, 2419. (b) Koumbis, A. E.; Gallos, J. K Curr. Org. Chem. 2003, 7, 585. (c) Revuelta, J.; Cicchi, S.; Goti A.; Brandi, A. Synthesis 2007, 485.

6. (a) Cardona, F.; Valenza, S.; Picasso, S.; Goti, A.; Brandi, A. J. Org. Chem. 1998, 63, 7311. (b) Duff, F. J.; Vivien, V.; Wightman, R. H. Chem. Commun. 2000, 2127.

7. Calinaud, P.; Gelas, J. Synthesis of Isopropylidene, Benzylidene, and Related Acetals. In Preparative Carbohydrate Chemistry; Hanessian, S., Ed.; Marcel Dekker, Inc.: New York, 1997, pp 3-33.

8. (a) Argyropoulos, N. G.; Panagiotidis, T.; Gallos, J. K. Tetrahedron: Asymmetry 2006, 17, 829. (b) Argyropoulos, N. G.; Panagiotidis, T.; Coutouli-Argyropoulou, E.; Raptopoulou C. Tetrahedron 2007, 63, 321.

9. (a) Carmona, A. T.; Whigtman, R. H.; Robina, I.; Helv. Chim. Acta 2003, 86, 3066. (b) Cardona, F.; Faggi, E.; Liguori, F.; Cacciarini, M.; Goti, A. Tetrahedron Lett. 2003, 44, 2315. (c) Desvergnes, S.; Sandrine, P.; Vallée Y. J. Org. Chem. 2005, 70, 1459. 
10. Coutouli-Argyropoulou, E.; Xatzis C.; Argyropoulos, N. G. Nucleosides Nucleotides \& Nucleic acids 2008, 27, 84.

11. Padwa, A.; Fišera, L.; Koehler, K. F.; Rodriguez, A.; Wong, G. S. K. J. Org. Chem. 1984, 49, 276. (b) Ali, S. A.; Almuallem, H. Tetrahedron 1992, 48, 5273. (c) Tejero, T.; Dondoni, A.; Rojo, I.; Merchán, F. L.; Merino, P. Tetrahedron 1997, 53, 3301. (d) Ishar, M. P. S.; Singh, G.; Kumar, K.; Singh, R. Tetrahedron 2000, 56, 7817. (e) Fischer, R.; Drucková, A.; Fišera, L.; Hametner, C. ARKIVOC 2002, (viii), 80. (f) Chiacchio, U.; Corsaro, A.; Iannazzo, D.; Piperno, A.; Pistarà, V.; Procopio, A.; Rescifina, A.; Romeo, G.; Romeo, R.; Siciliano, M. C. R.; Valveri, E. ARKIVOC 2002, (xi), 159.

12. (a) Tufariello, J. J. Acc. Chem. Res. 1979, 12, 396. (b) Tufariello, J. J.; Puglis, J. M. Tetrahedron Lett. 1986, 27, 1265. (c) Ali, S. A.; Khan, J. H.; Wazeer, M. I. M. Tetrahedron 1988, 44, 5911. (d) Ishikawa, T.; Tajima, Y.; Fukui, M.; Saito, S. Angew. Chem. Int. Ed. Engl. 1996, 35, 1863. (e) Hall, A.; Meldrum, K. P.; Therond P. R.; Wightman, R. H. Synlett $1997,123$. 